\title{
Hybrid
}

Revue des arts et médiations humaines

$6 \mid 2019$

L'écoute

\section{Music Beyond Digital : A Mooc, or How to Create what to Listen to}

Anne Sèdes, Dominique Saint-Martin and Christine Webster

Translator. Ana Wolf

OpenEdition

Journals

Electronic version

URL: https://journals.openedition.org/hybrid/620

DOI: $10.4000 /$ hybrid. 620

ISSN: 2276-3538

This article is a translation of:

La musique au-delà du numérique : composer l'écoute à travers un MOOC - URL : https:// journals.openedition.org/hybrid/611 [fr]

Publisher

Presses universitaires de Vincennes

\section{Electronic reference}

Anne Sèdes, Dominique Saint-Martin and Christine Webster, "Music Beyond Digital : A Mooc, or How to Create what to Listen to", Hybrid [Online], 6 | 2019, Online since 04 November 2019, connection on 15 April 2022. URL: http://journals.openedition.org/hybrid/620 ; DOI: https://doi.org/10.4000/hybrid.620

This text was automatically generated on 15 April 2022.

Revue Hybrid 


\title{
Music Beyond Digital : A Mooc, or How to Create what to Listen to
}

\author{
Anne Sèdes, Dominique Saint-Martin and Christine Webster \\ Translation : Ana Wolf
}

1 This edition of Hybrid is dedicated to Listening, and allows us to put out online 10 pieces of stereophonic electroacoustics, that were selected amungst the works of the Mooc learners Music beyond digital, a project which was set up on the platform Fun-Mooc during Fall 2018. ${ }^{1}$

2 Music beyond digital...The title of this Mooc, produced as part of the So Culture program ${ }^{2}$ of the ComUE Paris Lumières, in collaboration with l'INA GRL and the CICM, can seem enigmatic. In a certain sense, it was meant to underline the fact that beyond electroacoustic techniques and the relationship to digital audio technologies, music remains a matter of human mediation. At a time of mass digital development, music continues to create itself, between humans. Even through learning methods and knowledge sharings such as a Mooc.

Because the general audience has access to many creative tools via the internet, this Mooc gave us the opportunity to share knowledge, how to hear, how to listen, which are all at the heart of experimental music traditions that surfaced after World War II thanks to sound recording systems, that have since constantly evolved, integrating in its organology, musical computing and digital audio from the 1980s. What makes music, in a given environment, whether it be cultural or organological, is the act of listening, a human and social activity, that constructs and shares sensible knowledge, that fuels imagination and makes sense of interactions with a listening community.

4 In electroacoustic music, listening guides an operational activity, in an electroacoustic work environment that is mainly digital, a computer emulation of the recording studio. In a DAW, Digital Audio Workstation, where multiples softwares and tools are at play, listening determines the montage choices, transformation, mix, the setting of sound material.

5 Nowadays, you can make pop and electronic music with a cellphone, or you can use the said phone as a microphone. It was not the subject of the Mooc, but we should take a 
critical look at these approaches, because they lead us to a world of "ready to compose" music, where the automation of loops and the automatic processing of the electroacoustic chain give a completely standard result, preprocessed, pre-styled, to the point where it is possible to produce on a very professional level. But the creativity of listening, based on learning and knowing how to make sensitive choices from sound materials and their transformations, producing sensitive forms at various time levels of the musical moment being invented, is practically excluded from these trends, which also do not allow to produce historical and cultural connections other than based on stylistic mystifications storytold by the economy of the fan. As of today, listening tends to be something that carries you away, and is guided by digital rules with its streaming offers regulated by recommendation algorithms and a profiling of the listener. But that's another story.

Our approach was based on an introduction to creative music, learning by doing and experimenting, listening to sound material by working on its transformations, in a historically situated framework, that of electroacoustic music, from 1945 to present day. As always in music, learning through practice is crucial, based on the trial-anderror loop of make-listen and the sensitive choice deciding in the moment. Immersion in a community of listening and practice, sharing a reference repertoire, and ways of doing things, is essential. Anne Sedes and Dominique Saint-Martin have crosscompared our experiences in order to offer an educational sequence of 7 sessions that form an initiation course to electroacoustic music through practice. This course is conform to Anne Sedes' introductory class to electroacoustic, which is taught over the duration of a semester in the second year of musicology degree (Undergraduate) at Université Paris 8. It can also be thought of as an educational sequence such as the kind that high school music teachers set up to organize their lessons.

Each session included the following sections :

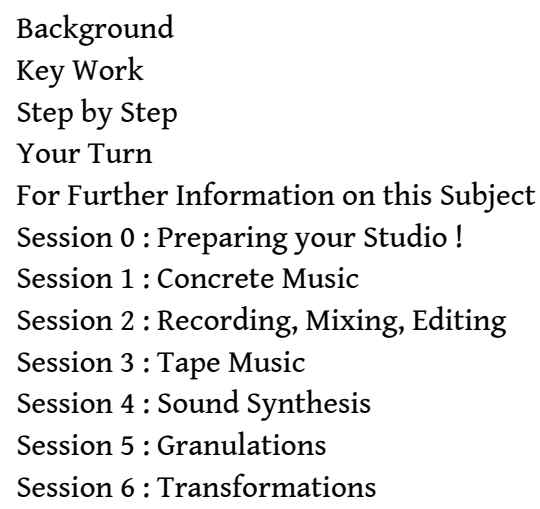

8 The filter of distance education courses could cause major difficulty. The forum, animated by Christine Webster (An electroacoustic composer, sound designer and who's well-versed in digital platforms.), made it possible to organize a continuois and constructive dialogue, between teachers and learners.

During each session, the learners were invited to post personal composition works, in response to specific instructions. To continue, they had to listen to and evaluate at least three works from their fellow peers, based on a few technical criteria such as ensuring compliance with the writing constraints of the session as well as the instructions, and the artistic quality. 


\section{NOTES}

1. https://www.fun-mooc.fr/courses/course-v1:parislumiere+142001+session01/about.

2. A collaboration with GRM, the musical research group of l'INA, and the CICM, the centre de recherche en informatique et création musicale/Musidanse of Universite Paris 8 So Culture is a partnership between Paris Lumières, Université Paris 8 - l'INA GRM (Institut national de l'audiovisuel - Groupe de recherches musicales), the Ile-de-France region and the European Union.

\section{AUTHORS}

\section{ANNE SÈDES}

She teaches electroacoustic composition for undergraduate students in musicology, in the « computer assisted» department of Paris 8. She co-wrote with Dominique Saint-Martin the Mooc "Music Beyond Digital », which is part of the So Culture program of the ComUE Universite Paris Lumière. 


\section{DOMINIQUE SAINT-MARTIN}

He is a musician and percussionist, pedagogue and head of the digital publishing projects of INA/ GRM.

\section{CHRISTINE WEBSTER}

She is an electroacoustic composer, a sound artist as well as a tutor animating the forums of the Mooc learning community. A specialist in virtual worlds, she is also a doctoral student in aesthetics, sciences and technologies of the arts, with a specialty in music at Paris 8 and at the Spatial Media Lab of ENSAD. She has been working on the VRAS project at EUR ArTeC since 2019. 